*ak RMIS View/Frint Document Cover Sheet tow

This document was retrieved from the Documentation and Records Manaqement (DRM) ISEARCH System. It is intended for Information only and may not be the most recent or updated version. Contact a Document Service Center (see Hanford Info for locations) if you need additional retrieval information.

Accession \#: D196037769

Document \#: SD-WM-OTP-199

Title/Desc:

OPERABILITY TEST PROCEDURE FOR THE ANNULUS THERMOCOUPLE TREE

Pages: 11 


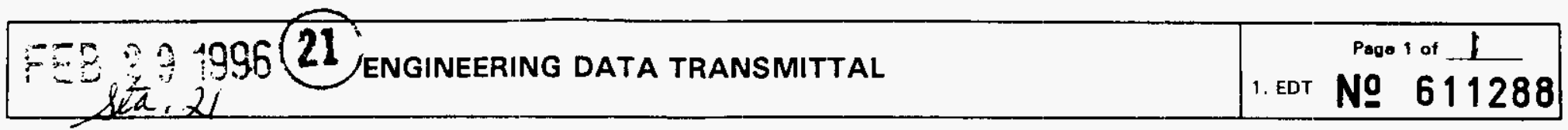

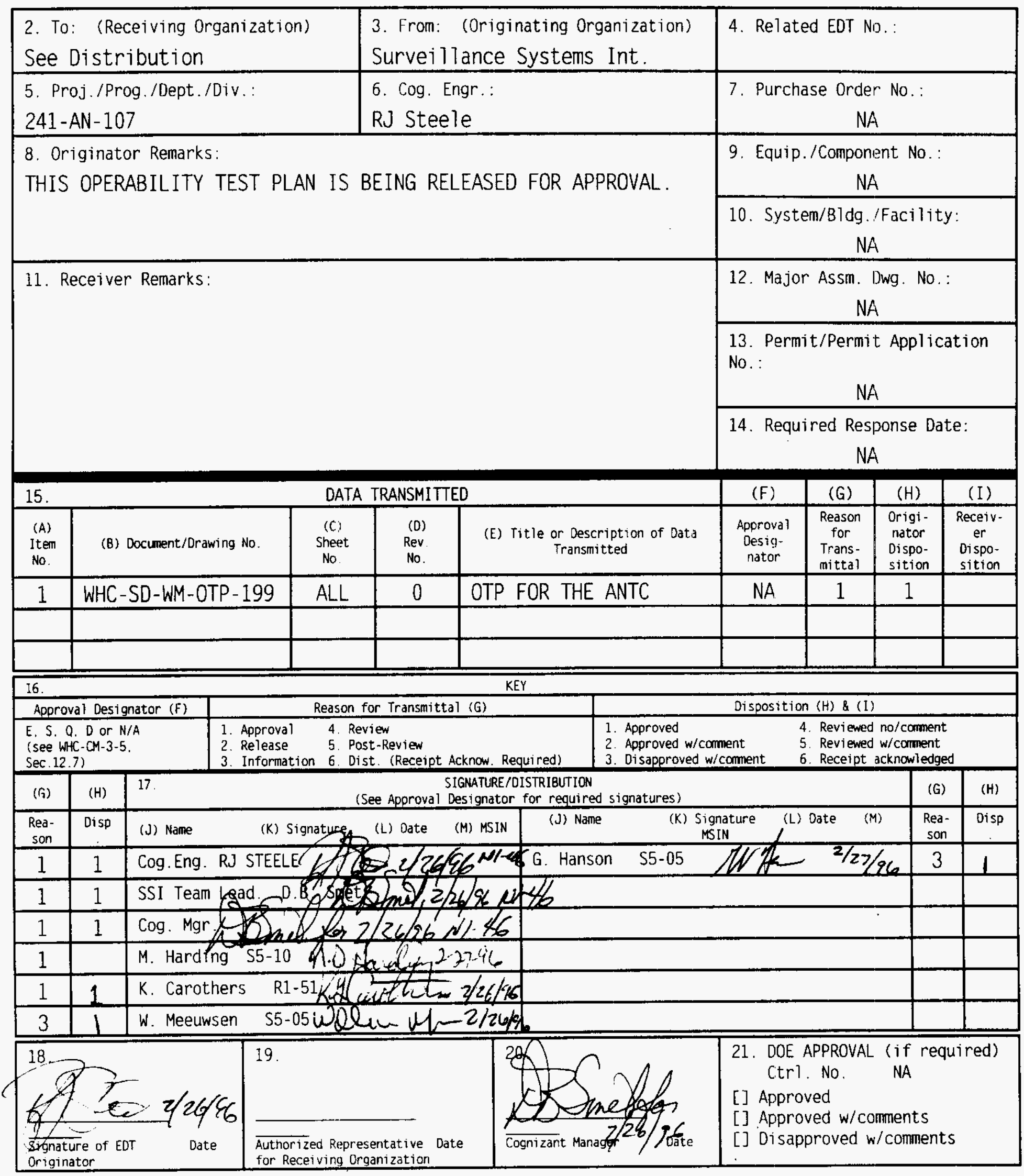

BD-7400-172.2(04/94) GEF097 


\section{OPERABILITY TEST PROCEDURE (OTP) FOR THE ANNULUS THERMOCOUPLE TREE}

R. J. Steele

Westinghouse Hanford Company. Richland, WA 99352

U.S. Department of Energy Contract DE-AC06-87RL10930

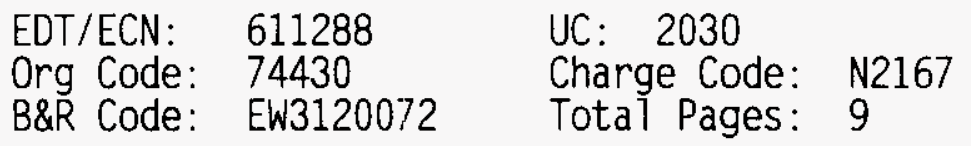

Key Words: 241-AN-107. Thermocouple tree, temperature

Abstract:

This document outlines the steps required to properly document the operability testing of this prototypical system.

TRADEMARK DISCLAIMER. Reference herein to any specific commercial product, process, or service by trade name, trademark, manufacturer, or otherwise, does not necessarily constitute or imply its endorsement, recommendation, or favoring by the United States Government or any agency thereof or its contractors or subcontractors.

Printed in the United States of America. To obtain copies of this document, contact: WHC/BCS

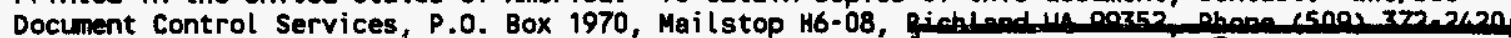
Fax (509) 376-4989.
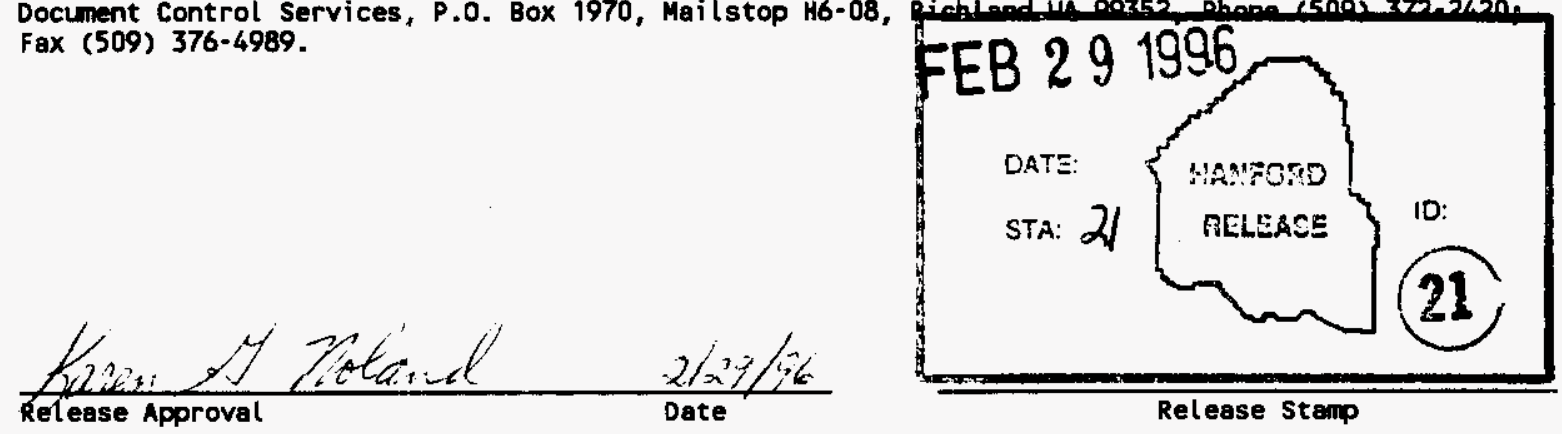

Release Stamp

\section{Approved for Public Release}




\section{OPERABILITY TEST PROCEDURE (OTP) FOR THE ANNULUS THERMOCOUPLE TREE}

Approval Designator: N/A

Robert J. Steele

Surveillance Systems Integration

February 5, 1996 


\section{TABLE OF CONTENTS}

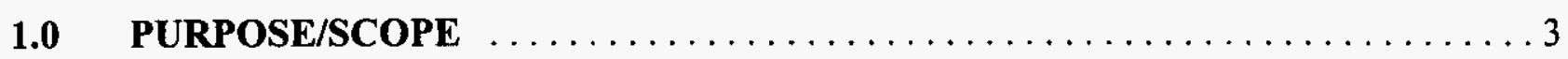

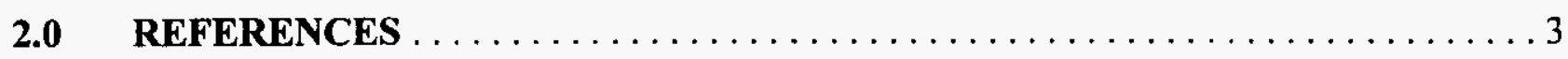

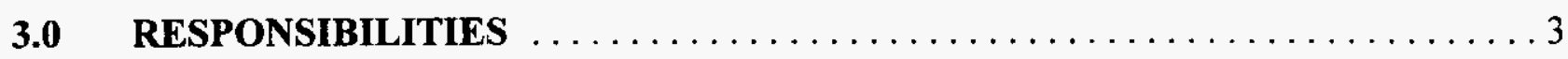

3.1 Surveillance Systems Integration $\ldots \ldots \ldots \ldots \ldots \ldots \ldots \ldots \ldots \ldots$

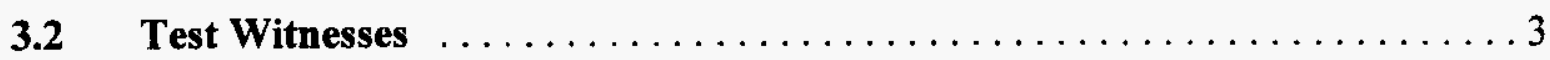

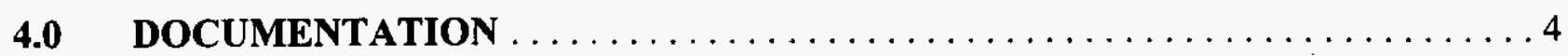

$4.1 \quad$ Test Records $\ldots \ldots \ldots \ldots \ldots \ldots \ldots \ldots \ldots \ldots \ldots \ldots \ldots \ldots \ldots$

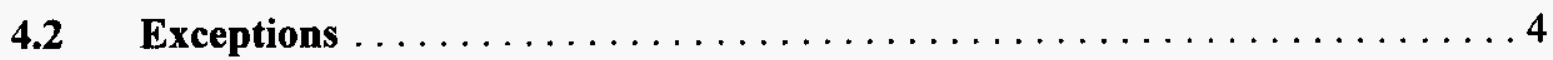

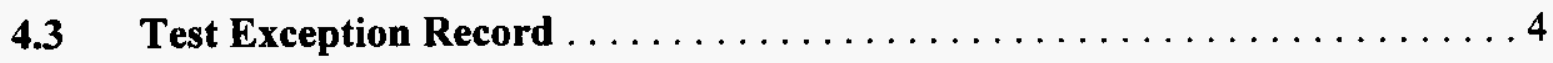

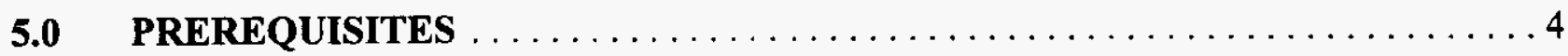

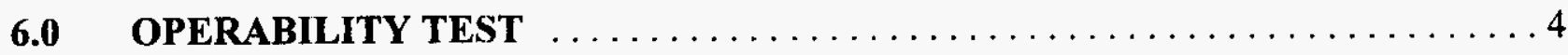

$7.0 \quad$ EXCEPTION TO OPERABILITY TEST $\ldots \ldots \ldots \ldots \ldots \ldots \ldots \ldots \ldots \ldots \ldots \ldots \ldots \ldots$

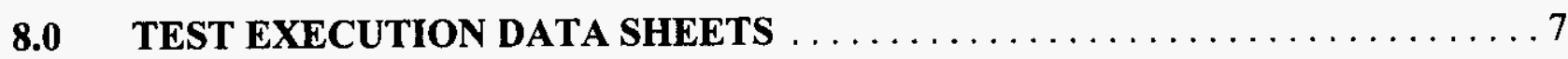

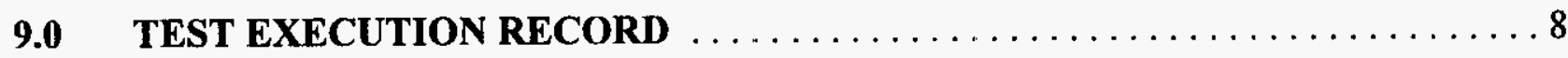

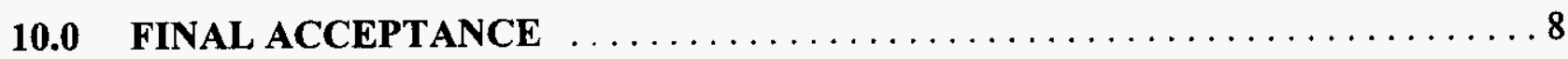




\section{OPERABILITY TEST PROCEDURE \\ OF THE \\ ANNULUS THERMOCOUPLE TREE (ANTC)}

\subsection{PURPOSE/SCOPE}

This Operability Test Procedure (OTP) provides step by step instructions for the functional testing of the Annulus Thermocouple Tree deployed into the annulus of underground nuclear waste storage tank 241-AN-107. The ANTC is designed to monitor the temperature gradient of the primary containment wall by using three arrays of contact thermocouples. The ANTC was deployed into the annulus under work plan WTWP-95015, package number 2E-95-0039. The final acceptance of this system will be based upon satisfactory completion of this test.

The acceptance criteria for successful completion of this operability test procedure involves verification of engagement of $100 \%$ of the electromagnets and thermocouples as well as temperature indication and recording of each thermocouple.

Test deviations and corrective actions will be addressed when anomalies arise. It is envisioned that no corrective actions will be taken if thermocouples do not engage the primary containment wall, but will be documented and deactivated on the computer. Minor adjustments will be required to place the footing magnets and array magnets in optimum position.

\subsection{REFERENCES}

N/A

\subsection{RESPONSIBILITIES}

\subsection{Surveillance Systems Integration (SSI)}

Surveillance Systems Integration shall provide and operate all the required equipment including computers, cabling, hardware, and the field control unit which houses the temperature measurement test equipment, power supplies, and associated hardware.

\subsection{Test Witnesses}

East Tank Farms Operations shall provide a Person In Charge (PIC), East Tank Farms Surveillance Operators, and any ancillary personnel and equipment required for this activity.

Test witnesses are responsible for verifying that organizational requirements are met throughout the testing and documentation sequences of the procedure. 


\subsection{DOCUMENTATION}

\subsection{Test Records}

All personnel involved in the performance of this test shall fill out applicable sections of this test procedure.

\subsection{Exceptions}

Exceptions by step number, and other notes shall be recorded in section 7 . This section must be dispositioned and signed off prior to final OTP approval. If no exceptions are encountered, this section shall be noted and closed out with the required signatures. Errors noted during the performance of this test shall be corrected to facilitate test completion. Each correction shall be noted and listed in section 7.0 of this procedure.

\subsection{Test Exception Record}

Approval of the OTP results shall be accepted by the Caustic Addition Project Engineer as indicated by signature in Section 7.0 and 10.0 .

\subsection{PREREQUISITES}

5.1 Work Plan WTWP-95-015 :Work Plan: "AN-107 Annulus Thermocouple Tree Installation and Removal" shall have the installation portion completed prior to the initiation of this operability test procedure.

\subsection{OPERABILITY TEST}

NOTE: The following steps should only be followed sequentially as they pertain to each ANTC.

6.1 Verify all Electromagnets engage the exterior of the primary containment wall as directed in WTWP-95-015.

ANTC 1:

SSI Cognizant Engineer

Date

ANTC 2:

SSI Cognizant Engineer

Date

ANTC 3:

SSI Cognizant Engineer

Date 
6.2 Verify all thermocouples engage the primary containment wall as directed in WTWP-95015.

ANTC 1:

$$
\text { SSI Cognizant Engineer }
$$

Date

ANTC 2:

$$
\text { SSI Cognizant Engineer }
$$

Date

ANTC 3:

SSI Cognizant Engineer

Date

6.3 Record the temperatures for all thermocouples on the data/verification sheets.

SSI Cognizant Engineer

Date

6.4 Verify all temperature data is recorded on the diskette in drive a: on the field computer at an interval of once every ten (10) minutes. 


\subsection{EXCEPTION TO OPERABILITY TEST}

\begin{tabular}{|l|l|l|l|l|}
\hline Step No. & Date & PAGE & DISCREPANCY & DISPOSITION \\
\hline & & & & \\
\hline & & & & \\
\hline & & & & \\
\hline & & & & \\
\hline & & & & \\
\hline
\end{tabular}

TEST APPROVED WITH EXCEPTIONS

SSI TEST ENGINEER

$\overline{\text { CAUSTIC ADDITION PROJECT ENGINEER }}$ 


\subsection{TEST EXECUTION DATA SHEETS}

DATE:

DOCUMENT NUMBER

SERIAL OR TEST NUMBER TITLE OF TEST:

TEST PERFORMED BY:

TABLE 1

\begin{tabular}{|c|c|l|}
\hline 241-AN-107 ANNUIUS THERMOCOUP E TREE TEMPERATURES \\
\hline 1 Thermocouple Number & ANTC Number & Temperature \\
\hline 2 & & \\
\hline 3 & & \\
\hline 4 & & \\
\hline 5 & & \\
\hline 6 & & \\
\hline 7 & & \\
\hline 8 & & \\
\hline 9 & & \\
\hline 10 & & \\
\hline 11 & & \\
\hline 12 & & \\
\hline 14 & & \\
\hline 15 & & \\
\hline 16 & & \\
\hline 18 & & \\
\hline 21 & & \\
\hline
\end{tabular}

TEST WITNESSES:

Cognizant Engineer

Date

Caustic Addition Project Engineer

Date 


\subsection{TEST EXECUTION RECORD}

\begin{tabular}{|c|c|c|}
\hline Reference Section & Accept/Reject & Remarks \\
\hline 6.1 & & \\
\hline 6.2 & & \\
\hline 6.3 & & \\
\hline 6.4 & & \\
\hline
\end{tabular}

\section{TEST WITNESSES}

SSI Test Engineer/Date

$\overline{\text { Caustic Addition Project Engineer/Date }}$

\subsection{FINAL ACCEPTANCE}

Testing per this procedure has been completed satisfactorily and the Annulus Thermocouple Tree is ready for be placed into service.

Caustic Addition Project Engineer Date

